\title{
Suction tube with pressure regulation: technical note
}

\author{
Sebastião Gusmão ${ }^{1}$ \\ Division of Neurological Surgery of the Hospital das Clínicas from the Federal University of Minas Gerais, Department of \\ Neurosurgery, Luxemburgo Hospital, Belo Horizonte, MG, Brazil.
}

\section{ABSTRACT}

We describe a new suction tube for microsurgical procedures which permit a precise control of the pressure of suction. The new device consists of a suction tube connected to a laterally placed sliding bar which progressively opens or closes a leak. The surgeon can readily adjust the suction pressure by moving slightly the sliding bar with his thumb or index finger up and down almost instantaneously.

\section{KEYWORDS}

Suction/instrumentation, suction/methods, microsurgery, neurosurgical procedures/instrumentation, neurosurgical procedures/methods.

\section{RESUMO}

Aspirador com pressão de sucção regulável: nota técnica

Descrevemos um novo aspirador para procedimentos microcirúrgicos que permite controle preciso da pressão de sucção. Consiste de tubo de aspiração conectado lateralmente com barra deslizante que abre ou fecha progressivamente uma fenda. O cirurgião pode ajustar rapidamente a pressão de sucção por meio de movimentação delicada da barra deslizante com o dedo indicador ou polegar.

\section{PALAVRAS-CHAVE}

Sucção/instrumentação, sucção/métodos, microcirurgia, procedimentos neurocirúrgicos/ instrumentação, procedimentos neurocirúrgicos/métodos.

\section{Introduction}

The suction tube is a multipurpose device which is used in neurosurgical procedures for suction, microdissection, and dynamic retraction. Fast and fine changes in suction pressure are usually required during surgery to avoid damage to the nervous system and vessels. Ideally, the suction pressure has to be prompt adjusted by the surgeon in a timely fashion according to the surgical situation. ${ }^{1}$

We described in another publication a new suction tube mechanism to control the suction pressure. ${ }^{2}$ Although the principle remains the same (a leak which is progressively opened or closed by a laterally placed sliding bar), the modification presented in this paper make the suction device simpler and more precise.

\section{Description of method}

The suction device consists of an aluminum tube which the central portion presents a triangular ex- ternal shape. In the tube there is a leak of $5 \times 1.7 \mathrm{~mm}$ which communicates with the internal side of the tube. Along one of the three faces slids a bar of Teflon (polytetrafluoroethylene). This bar runs up and down allowing variable degrees of closure of the leak. This forms the basis for the regulation of the suction pressure (Figure 1).

The tube can be manufactured in different lengths, diameters, shapes, and angles according to the surgeon's preference and needs.

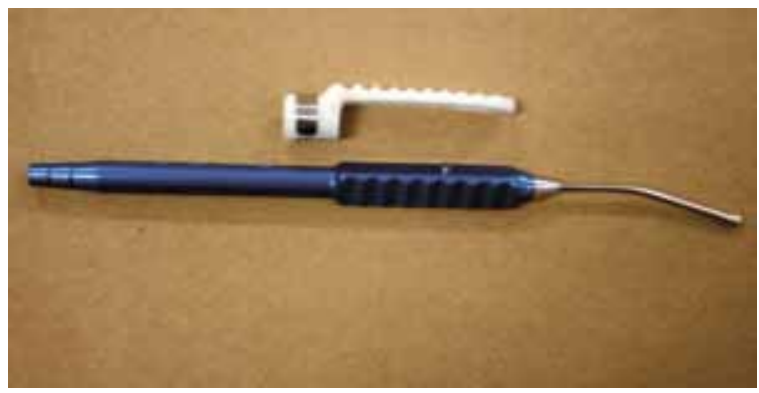

Figure 1 - Suction tube with aspiration pressure control.

1. Professor titular de Neurocirurgia da Universidade Federal de Minas Gerais (UFMG), coordenador do Serviço de Neurocirurgia do Hospital das Clínicas da UFMG, coordenador do Serviço de Neurocirurgia do Hospital Luxemburgo, Belo Horizonte, MG, Brasil. 


\section{Discussion}

The new upgrade for the previously described suction device is very simple and ergonomic. It permits the sliding of the bar up and down by the thumb or the index finger, while the pencil grip of the tube handle is kept hold (Figure 2). With little practice, the surgeon quickly learns how to rapidly and automatically adjust the suction pressure by thumb or index finger.

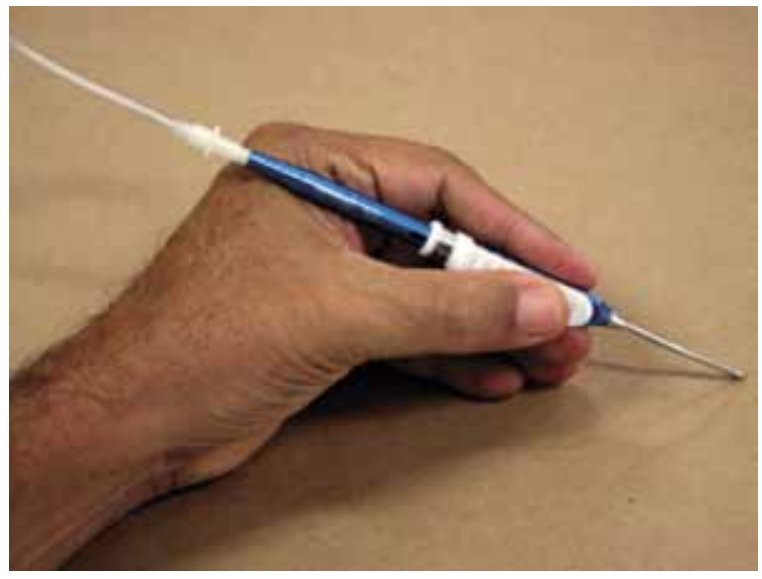

Figure 2 - Suction tube with aspiration pressure control held as a pencil by the surgeon by resting the hand in the surgical field.
The ideal suction tube for microneurosurgery has to have a small opening diameter and light weight, providing variable suction pressure. This pressure needs to move quickly from zero to a maximum and has to be controlled by the surgeon, keeping an easily and comfortably held and the fine hand movements which are required for microneurosurgery. The new upgrade proposed for the previous device combines all these characteristics.

\section{References}

1. Yasargil MG, Vise WM, Bader DC. Technical adjuncts in neurosurgery. Surg Neurol. 1977;8(5):331-6.

2. Gusmão S. A new device with pressure regulation for microsurgical suction: technical note. Surg Neurol. 2005;63(Suppl 1):S36-8.

\section{Correspondence address}

Sebastião Gusmão

Rua Padre Rolim, 921/21

30130-090 - Belo Horizonte, MG, Brazil

Telephones: (31) 3222-2547/(31) 9347-1888

E-mail: sebastiaogusmao@gmail.com 